\title{
GIS-based assessment of non-equilibrium pattern between groundwater recharge and irrigation draft in a semi-arid region of Rajasthan, India
}

\author{
Bidyut K BHADRA $^{1 *}$, Sanjay KUMAR ${ }^{2}$, Rakesh PALIWAL ${ }^{1}$ \\ ${ }^{1}$ Regional Remote Sensing Centre, National Remote Sensing Centre, Indian Space Research Organisation, Department of \\ Space, Jodhpur, Rajasthan 342003, India; \\ ${ }^{2}$ Krishi Vigyan Kendra, Central Arid Zone Research Institute, Indian Council of Agricultural Research, Bhuj, Gujarat 370105 , \\ India
}

\begin{abstract}
Over-exploitation of groundwater for irrigation can result in drastic reduction in groundwater level in Jodhpur district of western Rajasthan, India. In this study, we used the long-term trend analysis of seasonal groundwater level data to predict the future groundwater scenario in 33 villages of Jodhpur district, assessed the impact of water harvesting structures on groundwater recharge and explored the non-equilibrium between groundwater recharge and irrigation draft in the study area. Analysis of groundwater level data from 26 observation wells in 33 villages in the pre-monsoon period showed that groundwater level decreased continuously at the rate of $2.07 \mathrm{~m} / \mathrm{a}$. With this declining rate, most of the tube wells (including the well with the maximum depth of $193 \mathrm{~m}$ ) are predicted to become completely dry by 2050 . Behavior of temporal groundwater level data in the study period (from 2004 to 2012) can be explained by different geospatial maps, prepared using ArcGIS software. Statistical analysis of the interpolated maps showed that the area with the maximum positive groundwater recharge occupied $63.14 \%$ of the total area during 2010-2011 and the area with the maximum irrigation draft accounted for $56.21 \%$ of the total area during 2011-2012. Higher groundwater recharge is attributed to the increase in rainfall and the better aquifer condition. Spatial distribution for the changes of average groundwater recharge and draft (2008-2009 and 2011-2012) showed that 68.50\% recharge area was in positive change and $45.75 \%$ draft area was in negative change. It was observed that the area of the irrigation draft exceeded that of the groundwater recharge in most of the years. In spite of the construction of several shallow water harvesting structures in 2009-2010, sandstone aquifer zones showed meager impact on groundwater recharge. The best-fit line for the deviation between average groundwater fluctuation due to recharge and irrigation draft with time can be represented by the polynomial curve. Thus, over-exploitation of groundwater for agricultural crops has result in non-equilibrium between groundwater recharge and irrigation draft.
\end{abstract}

Keywords: geographic information system; groundwater fluctuation; water harvesting structures; Jodhpur district

Citation: Bidyut K BHADRA, Sanjay KUMAR, Rakesh PALIWAL. 2016. GIS-based assessment of non-equilibrium pattern between groundwater recharge and irrigation draft in a semi-arid region of Rajasthan, India. Journal of Arid Land, 8(2): 184-196. doi: 10.1007/s40333-015-0059-3

Over the past several years, there is a continuous demand of groundwater irrigation in agricultural sector throughout India, especially in arid and semi-arid regions (Karanth, 1987; Aswathanarayana, 2001). In spite of low rainfall intensity, groundwater is still being exploited

*Corresponding author: Bidyut K BHADRA (E-mail: bkbhadra63@gmail.com)

Received 2015-04-24; revised 2015-09-16; accepted 2015-10-26

(C) Xinjiang Institute of Ecology and Geography, Chinese Academy of Sciences, Science Press and Springer-Verlag Berlin Heidelberg 2016 
randomly in different parts of Rajasthan State, India. As a result, groundwater level declined drastically in the past few decades, resulting in over-exploitation in several zones of the state. Seasonal and temporal groundwater level data are the primary input parameters for generating the hydrogeological maps of pre-monsoon, post-monsoon and post-irrigation periods. Using these datasets, different groundwater situations in a region can be generated. Researchers have developed various methods to estimate groundwater recharge by using groundwater fluctuation and specific yield data (Gundogdu et al., 2000; Healy and Cook, 2002; Radhakrishna, 2003; Asanoa and Cotruvo, 2004; Crosbie et al., 2005; Maréchal et al., 2006; Ministry of Water Resources, Government of India, 2009). Similarly, groundwater draft has also been estimated by using different empirical formulas. For example, Ravikumar et al. (2005) developed a model with limited data (rainfall, temperature, lithology, groundwater level, agriculture and population) in ArcGIS to estimate groundwater draft in the upper Palar Basin, Tamil Nadu of India based on the indirect assessment of groundwater irrigation. Ministry of Water Resources, Government of India (2009) provided a method for estimating groundwater draft by multiplying its average discharge and annual working hours of a tube well. Khan et al. (2008) conducted a study on groundwater balance and crop area estimation in semi-arid regions of Andhra Pradesh, India by using remote sensing and geographic information system (GIS) tools. Different case studies have shown the progressive decline in groundwater level of India due to the increase in groundwater irrigation (Jahan et al., 2010; Shahid et al., 2015). Sharif and Ashok (2011) studied the cost of groundwater extraction and the impact of groundwater depletion in the Chamarajanagar district of Karnataka State, India. The variation of groundwater level in fractured aquifer system in a semi-arid region of Anantpur district has been studied by Reddy (2012), and the result showed steady declining trend in groundwater level (ranging from 0.50 to $2.91 \mathrm{~m} / \mathrm{a}$ ) because of groundwater exploitation. Surinaidu et al. (2012) developed a regional groundwater flow model for the upper Bhima River Basin in southern India. Their model predictions under different climate change and abstraction scenarios indicated that the continuation of current abstraction rates will lead to significant groundwater overdraft, with the fall in groundwater levels by $6.0 \mathrm{~m}$ over the next three decades. Hydro-chemical study of industrial pollutants indicates good aquifer response by alluvium for at least $3 \mathrm{~km}$ laterally along the Bandi River in Pali district of Rajasthan (Bhadra et al., 2013). The finding can be supported by higher groundwater fluctuation $(+15.61 \mathrm{~m})$ in 1990 due to higher rainfall $(1,236.6 \mathrm{~mm})$.

In view of the above situation, we used the long-term trend analysis of seasonal groundwater level data during 2004-2005 to 2011-2012 to predict the future groundwater scenario in a semi-arid region of Rajasthan, India. Spatial maps were generated for groundwater recharge and draft by using interpolation techniques and ArcGIS spatial analyst tool. The temporal relationship between groundwater fluctuation due to recharge and irrigation draft was shown along with the declining trend of groundwater level in this study. We also made an attempt to assess the impact of water harvesting structures on groundwater recharge and the non-equilibrium between groundwater recharge and irrigation draft in the study area.

\section{Hydrogeology of the study area}

Thar Desert covers an area of nearly $4.46 \times 10^{5} \mathrm{~km}^{2}$, which encompasses about $70 \%$ of the total land area of Rajasthan in India. It spreads dominantly in Jaisalmer, Barmer, Bikaner and Jodhpur districts. The annual rainfall in the Thar Desert varies from 100 to $500 \mathrm{~mm}$ from west to east. A broad outline of climate change and its impact on the Thar Desert ecosystem was given by Poonia and Rao (2013). The study area $\left(589.24 \mathrm{~km}^{2}\right)$ is comprised of 33 villages in Jodhpur district of Rajasthan, India (Fig. 1a). The area is bounded by $72^{\circ} 50^{\prime} \mathrm{E}$ to $73^{\circ} 01^{\prime} \mathrm{E}$ longitude and $26^{\circ} 19^{\prime} \mathrm{N}$ to $26^{\circ} 41^{\prime} \mathrm{N}$ latitude, which falls exclusively in sandstone aquifer zone (Fig. 1b). The IRS Resourcesat-2 LISS-IV satellite image of 21 February 2012 (Fig. 1c) shows that more than 70\% area is agricultural land (reddish tone on False Colour Composite) in the north and nearly 25\% area is wasteland with rocky outcrops in the south. Spatial location of the 26 observation wells in the study area shows that 16 wells lie in Osian block and 10 wells in Mandore block (Fig. 1d). All 


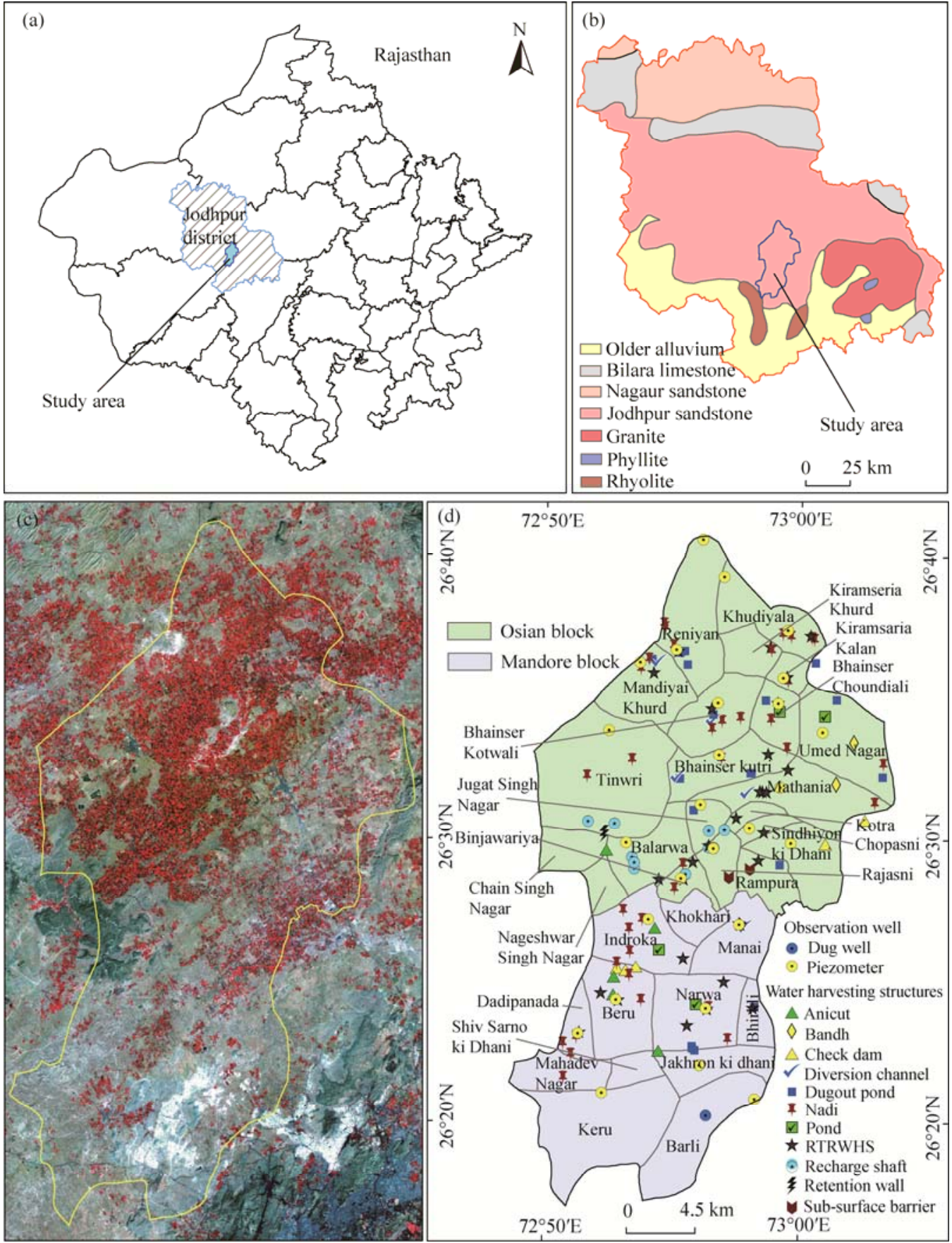

Fig. 1 Location map of the study area in Jodhpur district of Rajasthan, India (a), hydrogeological map of the study area and surrounding region (b), Resourcesat-2 LISS-IV (resolution of $5.8 \mathrm{~m}$ ) satellite image (February 2012) of Osian-Mandore area (c) and location map of observation wells and water harvesting structures in different villages of the study area (d). RTRWHS, roof top rain water harvesting structure.

these wells were constructed in sandstone aquifer with the depths of 32-193 $\mathrm{m}$. Among the 26 observation wells, 2 observation wells are at the depths of $<100 \mathrm{~m}, 16$ wells are in the depth range of $100-150 \mathrm{~m}$ and 8 wells fall within 150 to $193 \mathrm{~m}$ depths. In the study area, flood irrigation practices prevails with groundwater extraction from tube wells, and most of the farmers use open storage tanks to better manage groundwater. Although Rajiv Gandhi Lift Canal passes through the study area, it is used exclusively for domestic purposes. 
The major rock types in the study area belong to Jodhpur Group of Marwar Supergroup of Lower to Upper Proterozoic age (Pareek, 1984; GSI, 1985, 1993). Rocks of Jodhpur district belong to Jodhpur Group, Bilara Group and Nagaur Group (Fig. 1b). Jodhpur Group is comprised of Sonia and Girbhakar Formations with thickness between 125 and 240 m. Girbhakar sandstone is made up of yellow and purple sandstone, interbedded shale and clay siltstone. Thickness of the sandstone layer increases towards northwest of the area. Jodhpur Group of rocks is overlain by Quaternary sediments such as alluvium and aeolian sediments. Thickness of the alluvium in the north of Jodhpur is around 5-10 m with $1.5 \mathrm{~m}$ aeolian sediments. Jodhpur sandstone acts as the main aquifer formation in the study area (SRSAC, 1999).

For measuring the groundwater level in the study area, 118 water harvesting structures (WHS) were constructed during 2008-2009 (Fig. 1d). Among the 118 WHS, 36 structures are nadi (long earthen embankment with small height) and 21 are dugout ponds (mainly renovated old ponds/tanks/depression), and they are used to store rainwater in the monsoon season (July to September). Depending on the suitability of the area, 32 other WHS were also constructed, i.e. anicut, diversion channel, waste weir, check dam, pond, recharge shaft, retention wall and sub-surface barrier. Apart from these recharging structures, there are 29 roof top rainwater harvesting structures which are exclusively used for drinking water storage.

\section{Materials and methods}

Hydrogeological studies were carried out in the study area using temporal groundwater level data of 26 observation wells for pre-monsoon (April to June), post-monsoon (October to December) and post-irrigation (January to March) periods during 2004-2005 to 2011-2012 (www.wris.rajasthan.gov.in/modules/GIS/GISwelcomeNewMIS.aspx). The two crop calendars of the study area are Kharif season (July to October) and Rabi season (December to March next year). Major crops (i.e. groundnut, cotton, castor and vegetables) in Kharif season are grown through rain fed irrigation (www.nicra-icar.in); whereas crops (i.e. wheat, garlic, mustard and cumin) in Rabi season are cultivated using groundwater irrigation (CGWB, 2008).

All these datasets were analyzed by ArcGIS 9.3.1 software. Initially, groundwater level data of 26 observation wells were converted to groundwater elevation data with respect to the mean sea level. To represent the seasonal data (pre-monsoon, post-monsoon and post-irrigation) in the entire study area, all the groundwater elevation data were analyzed by the Kriging interpolation method. Kriging is a powerful statistical interpolation technique, and is used for a spatially correlated distance or directional bias in the data (Colin, 2004; Chai et al., 2011). This technique has been applied in India and abroad to analyze the spatial variation of groundwater level (Kumar and Remadevi, 2006; Gundogdu and Guney, 2007; Kamińska and Grzywna, 2014). Geo-statistical tools in ArcGIS 9.3.1 software were used for interpolating the point data. We also generated the zonal statistics of interpolated data to obtain the average value over the entire study area. Overlay analysis was done after converting interpolated maps (raster form) into vector form to identify the change in groundwater fluctuation due to recharge and irrigation draft.

Annual rainfall data of the study area derived from the Ground Water Department, Government of Rajasthan were analyzed for the period of 2004-2005 to 2011-2012. Graphical representation of annual rainfall pattern during 2004-2005 to 2011-2012 showed that rainfall in 2005-2006, 2008-2009 and 2010-2011 were higher than the average annual rainfall of $295.29 \mathrm{~mm}$ in the Jodhpur region. The drought year was 2009-2010 due to the least annual rainfall $(<151 \mathrm{~mm})$. Groundwater level fluctuation data in the study period was used for the estimation of groundwater fluctuation due to recharge by subtracting post-monsoon groundwater level from pre-monsoon groundwater level data. Similarly, groundwater fluctuation due to irrigation draft was estimated by subtracting post-irrigation groundwater level in Rabi season from post-monsoon groundwater level. These datasets were represented by interpolated maps for groundwater fluctuation corresponding to recharge and irrigation draft. The change in groundwater fluctuation due to recharge and draft during 2008-2009 (before the construction of WHS) and 2011-2012 (after the construction of WHS) was also analyzed through interpolated maps. Finally, the deviation between 
the average groundwater recharge and draft with time was represented by the polynomial function.

\section{Results and discussion}

Researchers have assessed the availability of groundwater resources based on the estimation of groundwater recharge and draft with various techniques in different countries, i.e. Mexico (Scott and Shah, 2004), Turkey (Gundogdu and Guney, 2007; Aksever et al., 2015), USA (Harou and Lund, 2008), Ghana (Lutz et al., 2015), China (Wang and Zhao, 2015), India (Scott and Shah, 2004; Kumar and Remadevi, 2006; Bhuiyan et al., 2009; Reddy, 2012; Surinaidu et al., 2012; Lakshmamma et al., 2015) and Bangladesh (Jahan et al., 2010; Shahid et al., 2015). In this study, we also discussed the results of groundwater recharge and draft in Jodhpur district of Rajasthan, India along with the rainfall pattern.

\subsection{Variation in groundwater level}

The variation in seasonal groundwater level for the periods of pre-monsoon, post-monsoon and post-irrigation from 2004-2005 to 2011-2012 was studied in detail (the original data were not shown) in Jodhpur district of Rajasthan, India. The results indicated that 18 observation wells had negative changes in groundwater level in all periods. The maximum negative change in groundwater level (37.6 to $39.4 \mathrm{~m}$ ) was noted at Balarwa village in the whole study period. Positive changes in groundwater level were observed in 3 villages (i.e. Barli, Jakhron ki Dhani and Bhainsar Kutri) during the periods of pre-monsoon ( 0.60 to $4.10 \mathrm{~m})$, post-monsoon $(0.40$ to $8.45 \mathrm{~m})$ and post-irrigation (0.75 to $2.25 \mathrm{~m}$ ) between 2004-2005 and 2011-2012. Further, the seasonal groundwater level data were used for the estimation of groundwater recharge and irrigation draft.

Trend analysis of temporal groundwater level data (2004-2005 to 2011-2012) was done by converting the groundwater level data into its elevation data. Using these datasets, we generated the interpolated maps by the zonal statistics tool in ArcGIS spatial analyst. The average groundwater elevation ranging from 183 to $197 \mathrm{~m}$ asl in the study area was observed. The data of seasonal groundwater elevation showed a wide variation during pre-monsoon, post-monsoon and post-irrigation periods. As the groundwater fluctuation was very fast in the post-monsoon and post-irrigation periods, the long-term trend analysis of groundwater elevation for the pre-monsoon period was preferred due to attainment of stability. The trend line of seasonal average groundwater elevation for the study period (2004-2005 to 2011-2012) is shown in Fig. 2.

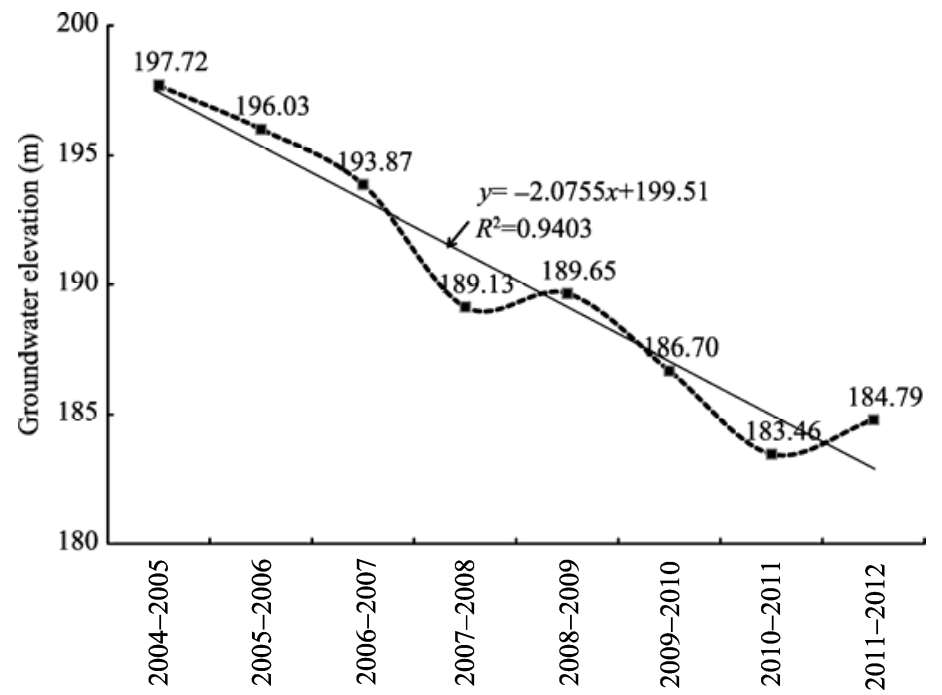

Fig. 2 Temporal variation in groundwater elevation in the pre-monsoon period during 2004-2005 to 2011-2012

The slope of the best-fit line $(-2.0755)$ represents the declination rate of groundwater level, i.e. $2.07 \mathrm{~m} / \mathrm{a}$. It can be predicted that with this declination rate, the deepest tube well at Rampura village $(193 \mathrm{~m})$ in the study area may completely get dry by 2050 . In contrary, the declining rate 
of long-term groundwater level (1997-2006) in the entire Jodhpur district was estimated as 0.17 to $0.89 \mathrm{~m} / \mathrm{a}(\mathrm{CGWB}, 2008)$.

\subsection{Groundwater recharge}

Water table fluctuation (WTF) method is the most widely used technique to estimate groundwater recharge (Healy and Cook, 2002; Aksever et al., 2015; Lakshmamma et al., 2015). In this study, we assessed the groundwater recharge in different villages of the study area from the groundwater level fluctuation. The results indicated that majority of the 26 observation wells showed negative recharge (fall in groundwater level) during 2004-2005 to 2011-2012 which is attributed to low rainfall $(<295.29 \mathrm{~mm})$. Further, negative groundwater level fluctuation may occur due to the following reasons, i.e. delayed recharge, and/or groundwater abstraction for irrigation in Kharif season (July to September). In contrast, due to higher rainfall, positive fluctuation (rise in groundwater level) was observed in a few villages during 2010-2011 $(1.32 \mathrm{~m})$ and 2011-2012 $(0.28 \mathrm{~m})$. Temporal variation of groundwater recharge in different change categories of groundwater level (fall $\geq 1 \mathrm{~m}$, fall $<1 \mathrm{~m}$, rise $<1 \mathrm{~m}$ and rise $\geq 1 \mathrm{~m}$ ) was analyzed for the periods from 2008-2009 to 2011-2012 (Table 1; Fig. 3). Groundwater recharge maps showed an increase in positive recharge area in the southern and eastern parts of the study area during 2010-2011 $(63.14 \%)$ and $2011-2012(60.43 \%)$ due to higher rainfall in comparison to the positive recharge area in 2008-2009 (19.28\%) and 2009-2010 (17.40\%). Among the 26 observation wells, fastest aquifer response due to recharge with respect to the rainfall pattern was observed during 2010-2011 in two villages, i.e. Barli $(5.30 \mathrm{~m})$ and Rampura $(14.60 \mathrm{~m})$. Thus, sandstone aquifer at shallow level acts as good natural recharge.

Table 1 Groundwater recharge area in different categories of groundwater level change during 2008-2009 to 2011-2012 from interpolated maps

\begin{tabular}{|c|c|c|c|c|c|c|c|c|}
\hline \multirow{3}{*}{ Period } & \multicolumn{4}{|c|}{ Negative recharge (fall in groundwater level) } & \multicolumn{4}{|c|}{ Positive recharge (rise in groundwater level) } \\
\hline & $\geq 1 \mathrm{~m}$ & $<1 \mathrm{~m}$ & Total & \multirow{2}{*}{$\begin{array}{c}\text { Area } \\
\text { percentage } \\
(\%)\end{array}$} & $<1 \mathrm{~m}$ & $\geq 1 \mathrm{~m}$ & Total & \multirow{2}{*}{$\begin{array}{c}\text { Area } \\
\text { percentage } \\
(\%)\end{array}$} \\
\hline & & Irea $\left(\mathrm{km}^{2}\right.$ & & & \multicolumn{3}{|c|}{ Area $\left(\mathrm{km}^{2}\right)$} & \\
\hline $2008-2009$ & 158.95 & 316.67 & 475.62 & 80.72 & 98.72 & 14.90 & 113.62 & 19.28 \\
\hline $2009-2010$ & 247.01 & 239.73 & 486.74 & 82.60 & 78.93 & 23.57 & 102.50 & 17.40 \\
\hline $2010-2011$ & 62.48 & 154.73 & 217.21 & 36.86 & 88.11 & 283.92 & 372.03 & 63.14 \\
\hline 2011-2012 & 11.39 & 221.79 & 233.18 & 39.57 & 261.79 & 94.27 & 356.06 & 60.43 \\
\hline
\end{tabular}

It was observed that fall in groundwater level was very marked $(\geq 1 \mathrm{~m})$ in the extreme north and northwestern parts of the study area during 2009-2010 in comparison to 2008-2009. With the increase in annual rainfall intensity in 2010-2011 and 2011-2012, this situation was improved tremendously with the rise in groundwater level $(\geq 1 \mathrm{~m})$ in the southern and northeastern parts of the study area. However, the amplitude of groundwater level fluctuation decreased in the northern and western parts of the study area. Thus, the southern and northeastern parts are the very good recharge zones (exposure of Jodhpur sandstone) in comparison to the northern and western parts (soil cover). Fast recharge of groundwater in the southern part may be attributed to higher runoff by the drainages and infiltration through fractures into sandstone aquifers (SRSAC, 1999; Todd and Mays, 2011).

\subsection{Groundwater draft}

The WTF method can also be applied for the estimation of groundwater draft in an area. Groundwater overdraft occurs when groundwater extraction exceeds both natural and induced aquifer recharge over long periods (Scott and Shah, 2004; Harou and Lund, 2008; Aksever et al., 2015). Groundwater fluctuation due to irrigation draft in different villages of the study area was estimated using the groundwater level data in the periods of post-monsoon and post-irrigation during 2008-2009 to 2011-2012. Data analysis showed an average negative groundwater fluctuation (fall in groundwater level) due to irrigation draft in the study area during 2004-2005 

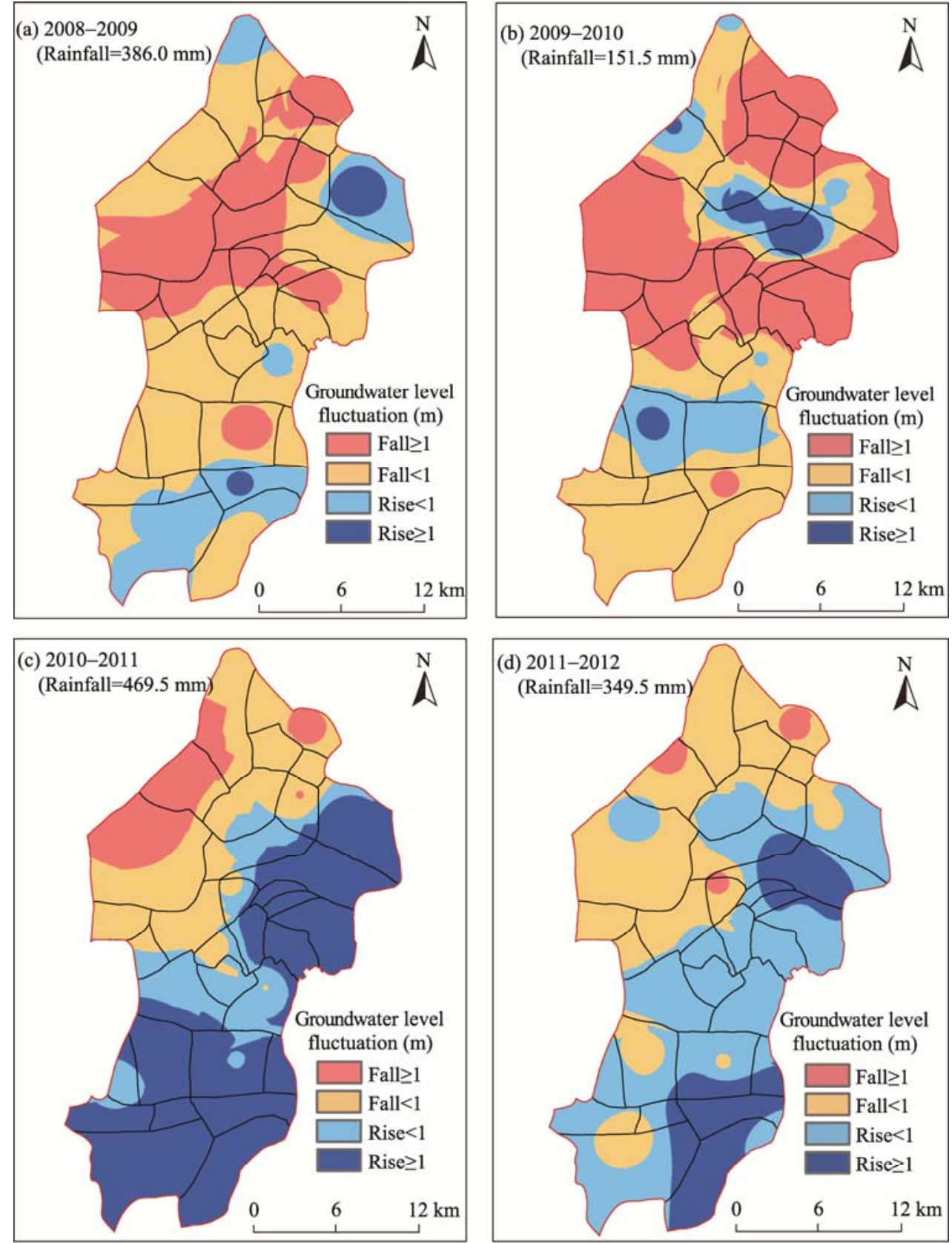

Fig. 3 Spatial distribution of groundwater level fluctuation due to recharge during 2008-2009 (a), 2009-2010 (b), 2010-2011(c) and 2011-2012 (d)

$(1.07 \mathrm{~m})$ to $2011-2012(2.19 \mathrm{~m})$. The maximum irrigation draft was observed in Rampura village (up to $15.10 \mathrm{~m}$ ) during 2010-2011. Exceptionally, Bhainser Kutri village showed a positive groundwater fluctuation (rise in groundwater level) in 2010-2011 (2.20 m) and 2011-2012 (0.70 m) because high rainfall.

Temporal variation in groundwater fluctuation with different categories of falling groundwater level (i.e. $<1,1-2,2-4$ and $\geq 4 \mathrm{~m}$ ) due to irrigation draft in Rabi season was analyzed for the periods of 2008-2009 to 2011-2012 (Table 2) by generating the interpolated maps for the same period (Fig. 4). The results showed that the extensive area under irrigation draft (fall in groundwater level of $\geq 2 \mathrm{~m}$ ) was observed in the eastern and southern parts of the study area 
Table 2 Groundwater draft area in different categories of falling groundwater level during 2008-2009 to 2011-2012 from interpolated maps

\begin{tabular}{|c|c|c|c|c|c|c|c|c|}
\hline \multirow{3}{*}{ Period } & \multicolumn{4}{|c|}{ Positive draft (fall in groundwater level of $<2 \mathrm{~m}$ ) } & \multicolumn{4}{|c|}{ Negative draft (fall in groundwater level of $\geq 2 \mathrm{~m}$ ) } \\
\hline & $<1 \mathrm{~m}$ & $1-2 \mathrm{~m}$ & Total & \multirow{2}{*}{$\begin{array}{c}\text { Area } \\
\text { percentage } \\
(\%)\end{array}$} & $2-4 \mathrm{~m}$ & $\geq 4 \mathrm{~m}$ & Total & \multirow{2}{*}{$\begin{array}{c}\text { Area } \\
\text { percentage } \\
(\%)\end{array}$} \\
\hline & & Area $\left(\mathrm{km}^{2}\right.$ & & & \multicolumn{3}{|c|}{ Area $\left(\mathrm{km}^{2}\right)$} & \\
\hline 2008-2009 & 145.60 & 183.00 & 328.60 & 55.77 & 245.58 & 15.06 & 260.64 & 44.23 \\
\hline 2009-2010 & 124.33 & 154.39 & 278.72 & 47.30 & 238.25 & 72.27 & 310.52 & 52.70 \\
\hline 2010-2011 & 374.50 & 103.13 & 477.63 & 81.06 & 61.67 & 49.94 & 111.61 & 18.94 \\
\hline 2011-2012 & 68.96 & 189.08 & 258.04 & 43.79 & 223.10 & 108.10 & 331.20 & 56.21 \\
\hline
\end{tabular}
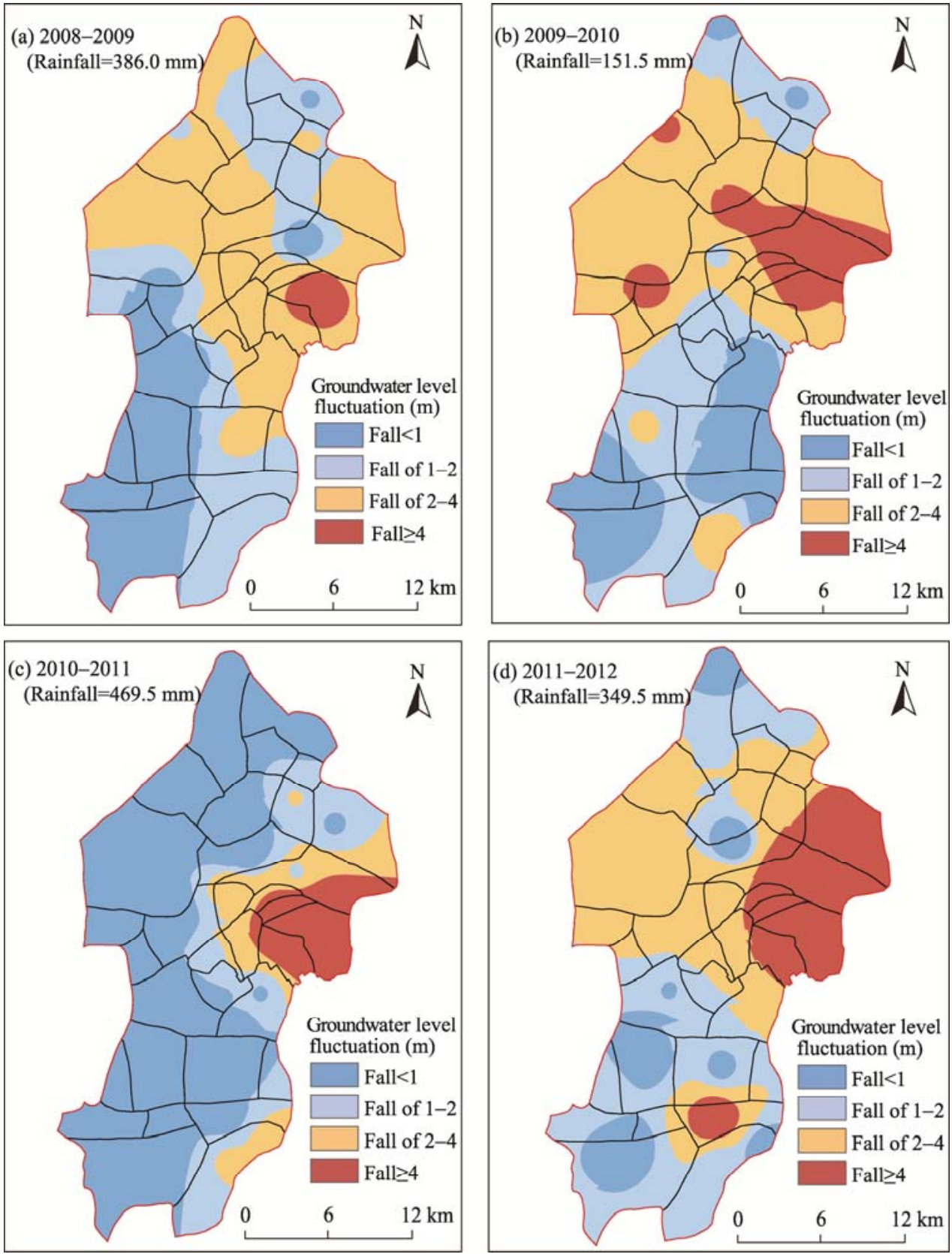

Fig. 4 Spatial distribution of groundwater level fluctuation due to irrigation draft during 2008-2009 (a), 2009-2010 (b), 2010-2011 (c) and 2011-2012 (d) 
during 2008-2009 (44.23\% of the total area), 2009-2010 (52.70\%) and 2011-2012 (56.21\%) (Table 2). Excessive withdrawal of groundwater under falling groundwater level of 2 to $4 \mathrm{~m}$ as well as $\geq 4 \mathrm{~m}$ was observed mostly in the central part of the study area. The situation of groundwater draft has improved (18.94\% of the total area) in 2010-2011 due to higher rainfall $(470 \mathrm{~mm})$, as depicted by lower groundwater level fluctuation (fall $<1 \mathrm{~m}$ ) in the western part of the study area. However, the situation was further deteriorated in 2011-2012 as groundwater draft went down (fall $\geq 2 \mathrm{~m}$ ) in different parts of the study area. This phenomenon may be attributed primarily to the excessive groundwater abstraction in Rabi season. Field verification with farmers' feedback indicated that groundwater abstraction was quite extensive in the study area due to prevailing flood irrigation practices for Rabi crops. In the study period, groundwater draft in Osian-Mandore area was very high especially during 2009-2010 (2.21 m/a) and 2011-2012 $(2.19 \mathrm{~m} / \mathrm{a})$. Field survey verified the drying up of many existing tube wells during 2008-2009 to 2011-2012. Moreover, farmers are forced to cultivate spices like cumin (crop with low water requirements) instead of chilly, due to the lack of groundwater availability for irrigation.

\subsection{Impact of water harvesting structures (WHS) on groundwater fluctuation}

To assess the impact of WHS on groundwater fluctuation in the study area, we conducted spatial change analyses for the areas of groundwater recharge and draft before (2008-2009) and after (2011-2012) the construction of WHS in 2009-2010. The change matrix of groundwater recharge area in different categories of groundwater level fluctuation between 2008-2009 and 2011-2012 is given in Table 3 . The bold values in Table 3 indicate no change in groundwater recharge area during 2008-2009 and 2011-2012. Moreover, the values above and below the bold values indicate positive and negative changes, respectively. It was observed that $27.47 \%$ of the geographical area was under falling groundwater level $(\geq 1 \mathrm{~m})$ in $2008-2009$, and $7.05 \mathrm{~km}^{2}$ area remained unchanged. Rest of the area was distributed in the groundwater level change categories of fall $<1 \mathrm{~m}$, rise $<1 \mathrm{~m}$ and rise $\geq 1 \mathrm{~m}$ in 2011-2012 with positive change. Similarly, positive impact of WHS on groundwater recharge may be assessed by increases in recharge area from 98.67 to $262.17 \mathrm{~km}^{2}$ under rising groundwater level of $<1 \mathrm{~m}$ and 14.91 to $94.45 \mathrm{~km}^{2}$ under rising groundwater level of $\geq 1 \mathrm{~m}$. Using this change matrix, we estimated the total groundwater recharge area with positive and negative changes during 2008-2009 and 2011-2012 (Fig. 5a). The spatial maps showed that the significant groundwater recharge area with positive change was $403.62 \mathrm{~km}^{2}(68.50 \%$ of the total area) and the recharge area with negative change was $37.54 \mathrm{~km}^{2}(6.37 \%)$. Thus, it may be argued that Osian-Mandore area represents the good recharge zones especially in villages like Tinwri, Bhainser Kutri, Mathania, Rampura, Indroka and Narwa, after the construction of WHS.

Table 3 Change matrix of groundwater recharge area before (2008-2009) and after (2011-2012) the construction of water harvesting structures in 2009-2010

\begin{tabular}{cccccccc}
\hline & & \multicolumn{5}{c}{ Groundwater recharge area in 2011-2012 $\left(\mathrm{km}^{2}\right)$} \\
\cline { 3 - 7 } & & Fall $\geq 1 \mathrm{~m}$ & Fall $<1 \mathrm{~m}$ & Rise $<1 \mathrm{~m}$ & Rise $\geq 1 \mathrm{~m}$ & Total & $\begin{array}{c}\text { Percentage } \\
(\%)\end{array}$ \\
& Fall $\geq 1 \mathrm{~m}$ & $\mathbf{7 . 0 5}$ & 106.73 & 45.37 & 2.73 & 161.88 & 27.47 \\
& Fall $<1 \mathrm{~m}$ & 4.35 & $\mathbf{8 8 . 9 8}$ & 159.96 & 60.49 & 313.78 & 53.25 \\
$\begin{array}{l}\text { Groundwater } \\
\text { recharge area }\end{array}$ & Rise $<1 \mathrm{~m}$ & 0.00 & 21.17 & $\mathbf{4 9 . 1 6}$ & 28.34 & 98.67 & 16.75 \\
$\begin{array}{l}\text { in 2008-2009 } \\
\left(\mathrm{km}^{2}\right)\end{array}$ & Rise $\geq 1 \mathrm{~m}$ & 0.00 & 4.34 & 7.68 & $\mathbf{2 . 8 9}$ & 14.91 & 2.53 \\
& Total & 11.40 & 221.22 & 262.17 & 94.45 & 589.24 & 100.00 \\
& $\begin{array}{c}\text { Percentage } \\
(\%)\end{array}$ & 1.93 & 37.54 & 44.49 & 16.03 & 100.00 & \\
\hline
\end{tabular}

Note: The bold values indicate no change in groundwater recharge area during 2008-2009 and 2011-2012. The values above and below the bold values indicate positive and negative changes in groundwater recharge area, respectively.

Similarly, the change matrix of groundwater draft area between 2008-2009 and 2011-2012 was generated for different categories of falling groundwater level, i.e. $<1,1-2,2-4$ and $\geq 4 \mathrm{~m}$ (Table 4). Values of groundwater draft area above and below the bold values also indicate negative and positive changes, respectively. Significant positive change was shown in 2011-2012 due to variation 
in draft area under falling groundwater level of $2-4\left(245.70 \mathrm{~km}^{2}\right), 1-2\left(38.01 \mathrm{~km}^{2}\right)$ and $<1 \mathrm{~m}(20.03$ $\mathrm{km}^{2}$ ). Using this change matrix (Table 4), interpolated maps for the change in groundwater draft area between 2008-2009 and 2011-2012 were generated (Fig. 5b). The spatial maps showed that negative changes of groundwater draft area occurred in more than $45 \%$ of the total area due to irrigation draft in Osian-Mandore area, i.e. Umed Nagar, Mathania, Balarwa, Chopasni, Rampura, Dedipanada and Jakhron ki Dhani with excessive withdrawal of groundwater in 2011-2012. However, positive changes were only observed in a few villages, i.e. Reniyan, Bhainser Kotwali, Bhainser Kutri and Narwa. Moreover, the rest of the villages showed almost no change in groundwater draft area before (2008-2009) and after (2011-2012) the construction of WHS.
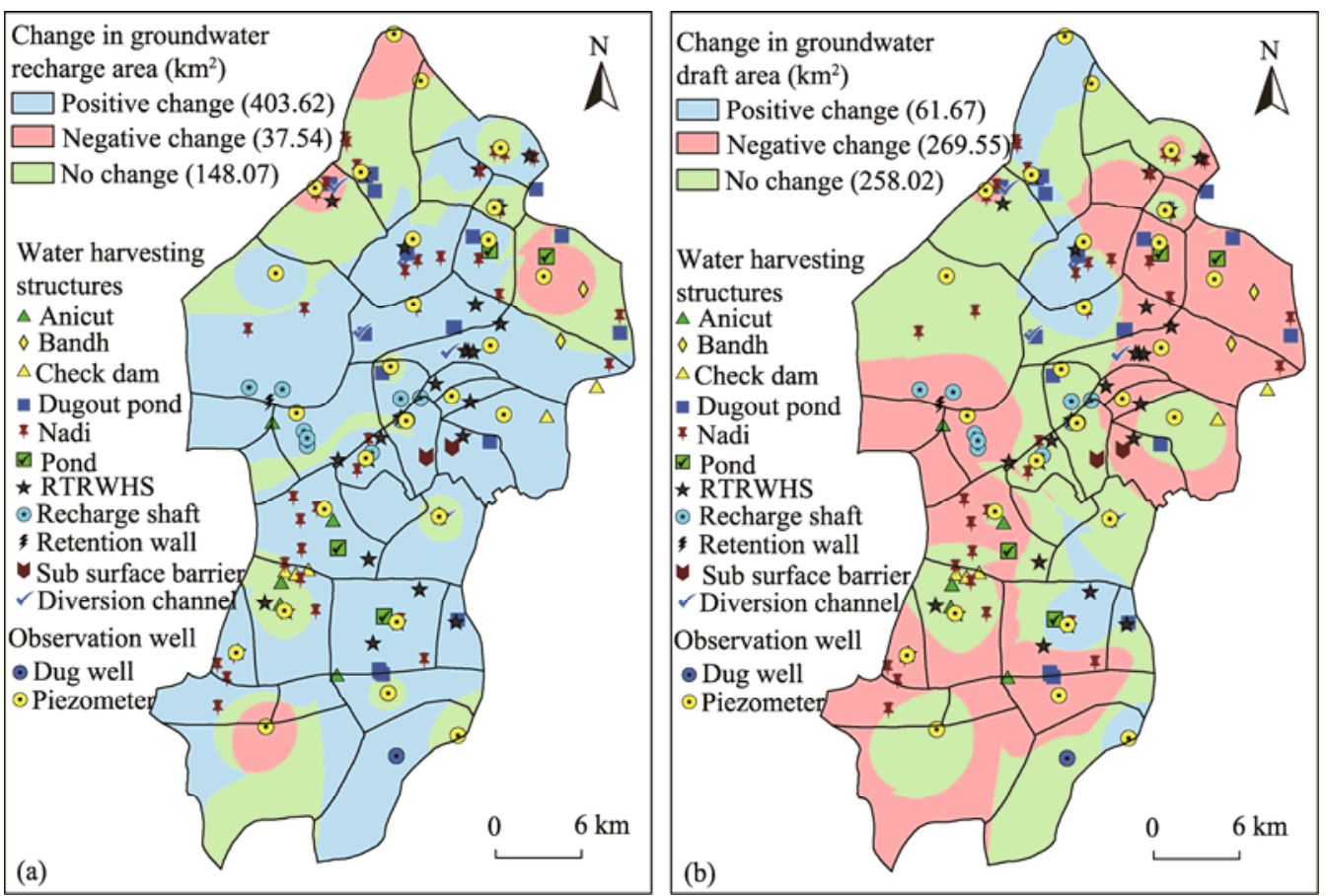

Fig. 5 Spatial patterns of changes in groundwater recharge area (a) and groundwater draft area (b) during 2008-2009 and 2011-2012 with the locations of water harvesting structures and observation wells

Table 4 Change matrix of groundwater draft area with falling groundwater level before (2008-2009) and after (2011-2012) the construction of water harvesting structures in 2009-2010

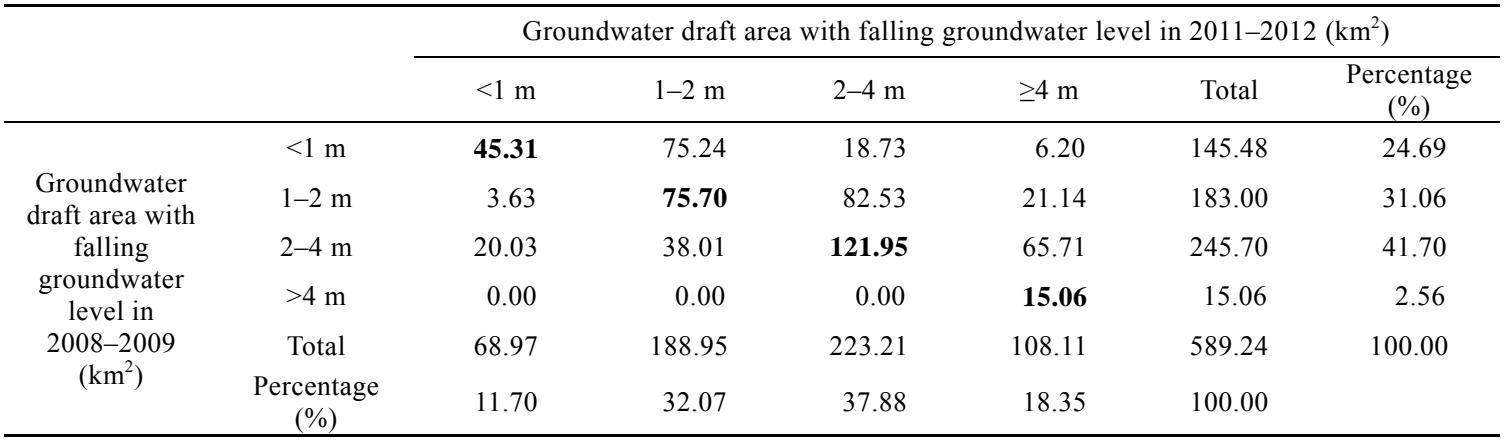

Note: The bold values indicate no change in groundwater recharge area during 2008-2009 and 2011-2012. The values above and below the bold values indicate positive and negative changes in groundwater recharge area, respectively.

\subsection{Non-equilibrium of groundwater recharge and irrigation draft}

Under natural conditions and over long periods of time (before water overuse), groundwater recharge is balanced by groundwater discharge to maintain an equilibrium stage in a region (Harou and Lund, 2008; Aksever et al., 2015). However, excessive groundwater withdrawal for 
irrigation with respect to recharge has resulted in rapid decline of groundwater level. Researchers have assessed the categorization of over-exploited and critical blocks in India based on groundwater resource estimation and groundwater utilization (Chatterjee and Purohit, 2009). The analysis showed that due to groundwater overuse (125\%), there are 140 over-exploited blocks and 50 critical blocks in Rajasthan where the annual groundwater draft $\left(12.99 \times 10^{9} \mathrm{~m}^{3}\right)$ exceeds the net annual groundwater availability $\left(10.38 \times 10^{9} \mathrm{~m}^{3}\right)$.

Groundwater fluctuation because of the non-equilibrium between groundwater recharge and irrigation draft during 2004-2005 to 2011-2012 can be assessed from the graphical representation of average recharge and draft with respect to average annual rainfall intensity (Fig. 6). Except the situation in 2007-2008, groundwater fluctuation due to irrigation draft always exceeded the groundwater recharge. The behavior of groundwater fluctuation due to recharge and draft between 2004-2005 and 2006-2007 was erratic with respect to annual rainfall. For example, both of average groundwater fluctuation due to recharge and draft were lower in spite of higher rainfall in 2005-2006. In contrary to the gap between groundwater fluctuations due to recharge and draft during 2004-2005 to 2007-2008, the deviation between the two parameters increased continuously during 2008-2009 to 2011-2012. For groundwater balancing in an area, the amount of groundwater recharge and draft should be in an equilibrium condition and commensurate with the rainfall. However, in the study area, a non-equilibrium condition existed between groundwater recharge and draft which was shown by the spatial interpolated maps (Figs. 3 and 4). The results indicated that groundwater draft was quite low in the southern part of the study area in spite of good recharge condition. However, groundwater draft as well as recharge was very high in the northeastern part of the study area.

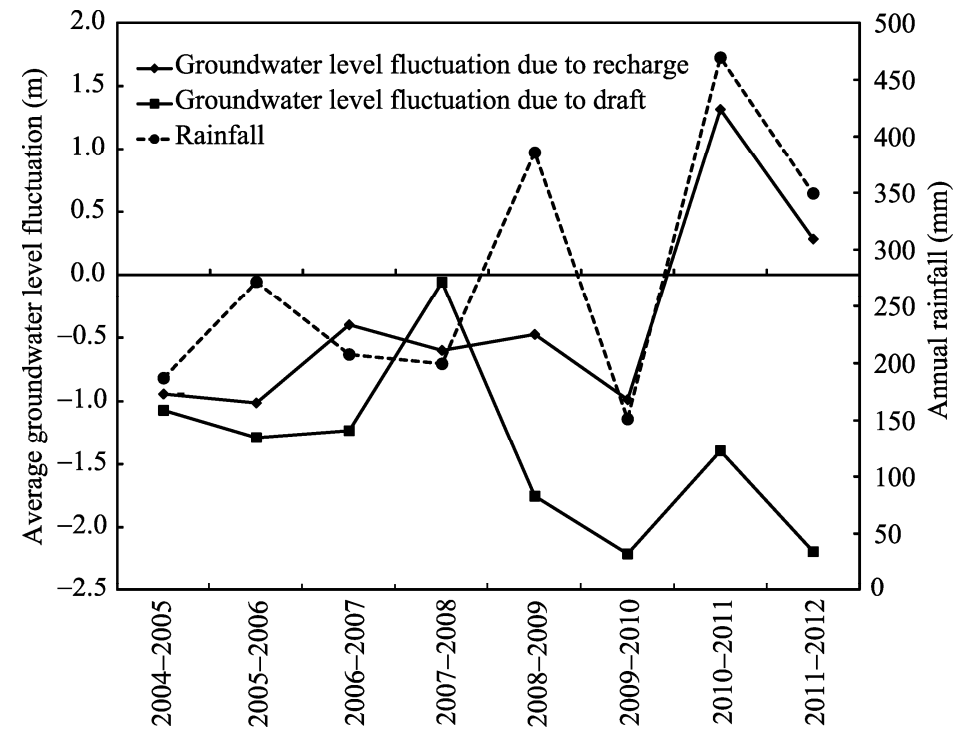

Fig. 6 Variation of average groundwater level fluctuation due to recharge and irrigation draft with respect to annual rainfall during 2004-2005 to 2011-2012

Scatter plots of the magnitude of deviation between the average groundwater level fluctuation due to recharge and irrigation draft $(y)$ for the corresponding years $(x)$ is shown in Fig. 7 . The $R^{2}$ value of the polynomial function is 0.7587 , which is higher than that of the linear best fit line (0.6678). Hence, the polynomial curve is preferred to than the linear relationship in this case. The polynomial relationship of this deviation with time indicated that groundwater draft area is increasing at faster rate with respect to groundwater recharge area, as reflected by the declination pattern of the temporal groundwater level (Fig. 3). According to this model, the gap between groundwater fluctuation due to recharge and draft in 2011-2012 will increase to 10 times during 2026-2027. The situation will reach to a critical stage in 2050 (drying of all the wells) and the gap will be enhanced by 46 times compared to that in 2011-2012. 


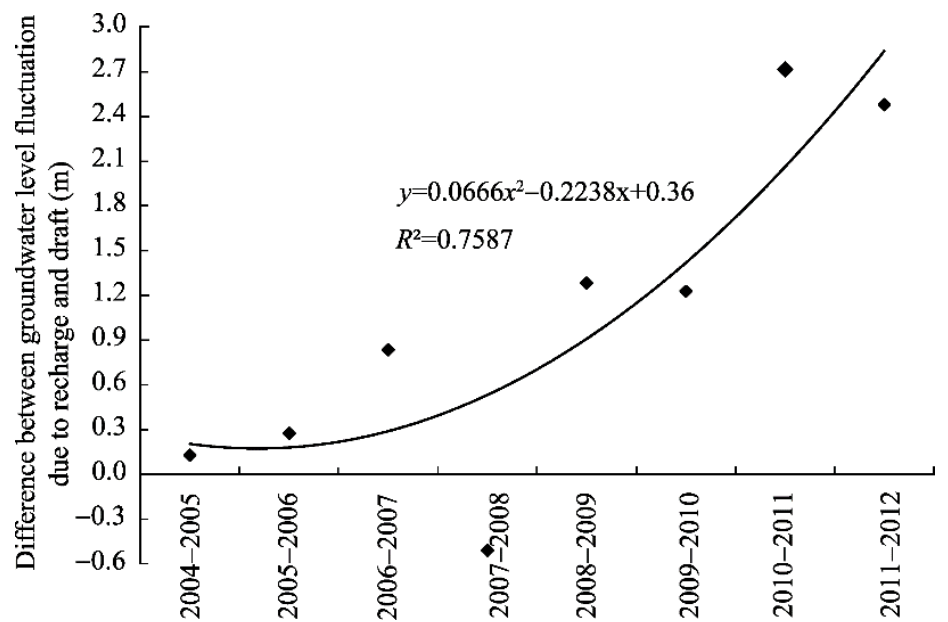

Fig. 7 Scatterplots of the deviation between average groundwater level fluctuation due to recharge and irrigation draft during 2004-2005 to 2011-2012

\section{Conclusions}

This study showed that groundwater level in Jodhpur district decreased at an alarming rate (2.07 $\mathrm{m} / \mathrm{a}$ ). Although a large number of water harvesting structures were constructed in the study area, they only showed a limited impact on groundwater recharge to augment the groundwater level fluctuation. Further, a critical situation of non-equilibrium stage was observed between the groundwater recharge and irrigation draft. The polynomial relationship of the deviation between groundwater recharge and draft in the study period (2004-2012) indicated a degraded trend of groundwater level in the study area. However, the situation can be changed with proper groundwater management practices such as minimizing groundwater withdrawal, shifting flood-water to sprinkler irrigation practices, altering cropping with low-water requirement and constructing more effective water harvesting structures.

\section{Acknowledgements}

Authors are grateful to the director of National Remote Sensing Centre (NRSC), Hyderabad and the chief general manager of Regional Centres/NRSC, Hyderabad for their inspiration to carry out the present work. We also thank the general manager of Regional Remote Sensing Centre-West, Jodhpur for his kind support and cooperation. Ground Water Department, Government of Rajasthan has kindly provided the temporal groundwater level data.

\section{References}

Aksever F, Davraz A, Karaguzel R. 2015. Groundwater balance estimation and sustainability in the Sandiklı Basin (Afyonkarahisar/Turkey). Journal of Earth System Science, 124(4): 783-798.

Asano T, Cotruvo J A. 2004. Groundwater recharge with reclaimed municipal wastewater: health and regulatory considerations. Water Research, 38(8): 1941-1951.

Aswathanarayana U. 2001. Water Resources Management and the Environment. New York: CRC Press.

Bhadra B K, Pathak S, Sharma J R. 2013. Impact of industrial effluents on groundwater around Pali City, Rajasthan using field and satellite data. Journal of the Geological Society of India, 82(6): 675-691.

Bhuiyan C, Singh R P, Flügel W A. 2009. Modelling of ground water recharge-potential in the hard-rock Aravalli terrain, India: a GIS approach. Environmental Earth Sciences, 59(4): 929-938.

CGWB (Central Ground Water Board). 2008. Groundwater scenario: Jodhpur district, Rajasthan. In: District Groundwater Brochure, CGWB, Ministry of Water Resources, Government of India. [2015-08-31]. http://www.cgwb.gov.in.

Chai H X, Cheng W M, Zhou C H, et al. 2011. Analysis and comparison of spatial interpolation methods for temperature data in Xinjiang Uygur Autonomous Region, China. Natural Science, 3(12): 999-1010.

Chatterjee R, Purohit R R. 2009. Estimation of replenishable groundwater resources of India and their status of utilization. Current Science, 96(12): 1581-1591.

Childs C. 2004. Interpolating surfaces in ArcGIS spatial analyst. In: ArcUser, ESRI Education Services, July-September 2004. 
http://www.esri.com/news/arcuser/0704/files/interpolating.pdf.

Crosbie R S, Binning P, Kalma J D. 2005. A time series approach to inferring groundwater recharge using the water table fluctuation method. Water Resources Research, 41(1): W01008, doi: 10.1029/2004WR003077.

GSI (Geological Survey of India). 1985. Geological Quadrangle Map of Jodhpur, Sheet No. 45F (1: 250, 000). Geological Survey of India, India. http://www.portal.gsi.gov.in.

GSI (Geological Survey of India). 1993. Geological Quadrangle Map of Shergarh, Sheet No. 45B (1: 250, 000). Geological Survey of India, India. http://www.portal.gsi.gov.in.

Gundogdu A, Yazicigil H, Kirmizitas H. 2000. Comparison of groundwater recharge estimation techniques: A case study from the Küçük Menderes River basin in Turkey. In: Proceedings of International Symposium on Integrated Water Resources Management. California: IAHS, 272: 417-423.

Gundogdu K S, Guney I. 2007. Spatial analyses of groundwater levels using universal Kriging. Journal of Earth System Science, 116(1): 49-55.

Harou J J, Lund J R. 2008. Ending groundwater overdraft in hydrologic-economic systems. Hydrogeology Journal, 16(6): 1039-1055.

Healy R W, Cook P G. 2002. Using groundwater levels to estimate recharge. Hydrogeology Journal, 10(1): 91-109.

Jahan C S, Mazumder Q H, Islam A T M M, et al. 2010. Impact of irrigation in Barind area, NW Bangladesh-An evaluation based on the meteorological parameters and fluctuation trend in groundwater table. Journal of the Geological Society of India, 76(2): 134-142.

Kamińska A, Grzywna A. 2014. Comparison of deteministic interpolation methods for the estimation of groundwater level. Journal of Ecological Engineering, 15(4): 55-60.

Karanth K R. 1987. Ground Water Assessment: Development and Management. New Delhi: Tata Mcgraw-Hill, 1-720.

Khan H H, Nabi A, Perrin J, et al. 2008. Remote sensing and GIS in estimating groundwater balance in semi-arid regions. In: Proceedings of the $3^{\text {rd }}$ International Conference on Water Resources and Arid Environments. $1^{\text {st }}$ Arab Water Forum, 1-9. https://scholar.google.nl/citations?user=hovy-DQAAAAJ\&hl=nl\&oi=sra.

Kumar V, Remadevi. 2006. Kriging of groundwater levels - A case study. Journal of Spatial Hydrology, 6(1): 81-92.

Lakshmamma, Nagaraju D, Balasubramanian A, et al. 2015. Estimation of groundwater recharge studies in Gundal watershed, Gundlupet Taluk, Chamarajanagar District, Karnataka, India using remote sensing and GIS. International Journal of Current Engineering and Technology, 5(3): 2138-2148.

Lutz A, Minyila S, Saga B, et al. 2015. Fluctuation of groundwater levels and recharge patterns in Northern Ghana. Climate, 3(1): 1-15.

Maréchal J C, Dewandel B, Ahmed S, et al. 2006. Combined estimation of specific yield and natural recharge in a semi-arid groundwater basin with irrigated agriculture. Journal of Hydrology, 329(1-2): 281-293.

Ministry of Water Resources, Government of India. 2009. Ground water resource estimation methodology. In: Report of the Ground Water Resource Estimation Committee. Ministry of Water Resources, Government of India, New Delhi, 1-113.

Pareek H S. 1984. Pre-Quaternary geology and mineral resources of northwestern Rajasthan. Memoirs of the Geological Survey of India, 115: 1-99.

Poonia S, Rao A S. 2013. Climate change and its impact on Thar desert ecosystem. Journal of Agricultural Physics, 13(1): 71-79.

Radhakrishna B P. 2003. Groundwater recharge. Journal of Geological Society of India, 62: 135-138.

Ravikumar G, Shahidhar T, Krishnaveni M, et al. 2005. GIS based groundwater quantity assessment model. International Journal of Civil and Environmental Engineering, 1(2): 21-30.

Reddy A G S. 2012. Water level variations in fractured, semi-confined aquifers of Anantapur district, southern India. Journal of the Geological Society of India, 80(1): 111-118.

Scott C A, Shah T. 2004. Groundwater overdraft reduction through agricultural energy policy: Insights from India and Mexico. International Journal of Water Resources Development, 20(2): 149-164.

Shahid S, Wang X J, Rahman M M, et al. 2015. Spatial assessment of groundwater over-exploitation in northwestern districts of Bangladesh. Journal of the Geological Society of India, 85(4): 463-470.

Sharif M, Ashok K R. 2011. Impact of groundwater over-draft on farm income and efficiency in crop production. Agricultural Economics Research Review, 24(2): 291-300.

SRSAC (State Remote Sensing Application Centre). 1999. Groundwater Atlas of Rajasthan. Jodhpur: State Remote Sensing Application Centre (SRSAC), Government of Rajasthan, 1-551.

Surinaidu L, Bacon C G D, Pavelic P. 2012. Agricultural groundwater management in the Upper Bhima Basin, India: Current status and future scenarios. Hydrology and Earth System Sciences Discussions, 9(9): 10657-10686.

Todd D K, Mays L W. 2011. Groundwater Hydrology ( $3^{\text {rd }}$ ed.). New Delhi: Publishing Wiley India Pvt Ltd., 1-635.

Wang G H, Zhao W Z. 2015. The spatio-temporal variability of groundwater depth in a typical desert-oasis ecotone. Journal of Earth System Science, 124(4): 799-806. 